\title{
GROWTH, BIOMASS ALLOCATION AND PHOTOSYNT HESIS OF Rolandra fruticosa (ASTERACEAE) IN RESPONSE TO SHADE ${ }^{1}$
}

\author{
MOACYR B. DIAS-FILHO² e ALOISIO F. CHAGAS JÚNIOR ${ }^{3}$
}

\section{ABSTRACT}

The effects of shade on growth, biomass allocation patterns and photosynthetic response was examined for Rolandra fruticosa (L.) Kuntze, a common perennial weed shrub in cultivated pastures and agricultural areas of Brazilian Amazonia, for plants grown in full sunlight and those shaded to $30 \%$ of full sunlight over a 34-d period. Specific leaf area and leaf area ratio were higher for shade plants during all the experimental period. Shade plants allocated significantly less biomass to root tissue than sun plants and relative growth rate was higher in sun plants. Sun leaves had significantly higher dark respiration and light saturated rates of photosynthesis than shade leaves. The apparent quantum efficiency was higher for shade leaves, while light compensation point was higher for sun leaves. These results are discussed in relation to their ecological and weed management implications.

Key words: Specific leaf area, leaf area ratio, growth analysis, tropics.

\section{RESUMO}

\section{Crescimento, alocação de biomassa e fotossíntese de Rolandra fruticosa (asteraceae) em resposta ao sombreamento}

Estudou-se o efeito do sombreamento no crescimento, alocação de carbono e respostas fotossintéticas de Rolandra fruticosa (L.) Kuntze, uma planta daninha de porte arbustivo, comum em áreas de pastagem e agrícolas da Amazônia Brasileira, submetida a condições de pleno sol e a $70 \%$ de interceptação da luz solar, durante 34 dias. A área foliar específica e a razão de área foliar foram maiores nas plantas sombreadas durante todo o período experimental. Plantas sombreadas alocaram menor quantidade de biomassa para as raízes, quando comparadas às plantas de sol e a taxa de crescimento relativo foi maior para as plantas de sol. A respiração no escuro e a taxa de fotossíntese máxima foram maiores para as folhas de plantas não sombreadas. A eficiência quântica aparente foi maior para as folhas de plantas sombreadas, enquanto que o ponto de compensação de luz foi maior para folhas a pleno sol. Esses resultados são discutidos com relação as suas importâncias ecológica e de manejo.

Palavras chave: Área foliar específica, razão de área foliar, análise de crescimento, trópicos.

\section{INTRODUCTION}

Light has a significant role in the competitive ability of plants and is a major determinant of their occurrence in certain environments (Ogren \& Sundin, 1996; Patterson, 1995; Sultan et al. 1998). In agricultural ecosystems like tropical pastures, the plant

\footnotetext{
${ }^{1}$ Received for publication on 18/02/99 and in the revised form on 16/05/99.

${ }^{2}$ Research agronomist, Ph.D., Lab. Ecofisiologia Vegetal, Embrapa Amazônia Oriental, Caixa Postal 48, CEP 66017-970, Belém-PA, Brazil, e-mail: moacyr@ cpatu.embrapa.br. CNPq fellow.

${ }^{3}$ Graduate Student, INPA, Manaus-AM, Brazil, Former PIBIC/CNPq fellow.
} 
community can be subjected to contrasting light environments over relatively small areas. In these environments, weed seedlings may have to start their development under conditions of permanent shade or, during their development, be shaded by the fast growing tropical grasses or pasture weeds (Dias Filho, 1990).

The ability of an individual weed species to successfully grow in a low or high light environment (holding quality constant) can be assessed by determining how efficiently and how rapidly allocation patterns and physiological behavior are adjusted in response to a particular light environment (Dias Filho, 1995; 1997; Holt, 1995). Therefore, information on the morphological and physiological responses of weedy species to distinct light conditions can be critical in determining their occurrence potential and in helping to understand their competitive ability under different management situations so as to devise more effective control strategies.
Rolandra
fruticosa
(L.) Kuntze

(Asteraceae), is a 0.4 to $0.7 \mathrm{~m}$ high shrubby weed species found in pastures and agricultural areas in Brazilian Amazonia (Dias Filho, 1990). According to the Specimen Data Base from the Missouri Botanical Garden examined by the first author, this species is also found in Venezuela, Colombia, Nicaragua, Panama and Puerto Rico.

Although seeds of $R$. fruticosa do not germinate under complete darkness, they can germinate under deep shade (M. B. Dias-Filho, unpublished data). Like most shrubby weeds from Amazonian pastures, this species sometimes has to start its development under deep shade or, more commonly, during its development, be shaded by the fast growing grasses or pasture weeds (Dias Filho, 1990).

The objective of the present study was to evaluate the acclimation capacity (phenotypic adjustment) of $R$. fruticosa to reduced light environment by examining the effects of shade on growth, biomass allocation patterns and photosynthetic response of this species under semi-controlled conditions.

\section{MATERIALS AND METHODS}

\section{Plant material and growing conditions}

Seeds of Rolandra fruticosa (L.) Kuntze $(=R$. argentea Rottb.) collected from plants in degraded pasture areas in eastern Brazilian Amazonia were germinated on sand and then planted individually in pots with $2.5 \mathrm{~kg}$ (dry mass) of soil (1:1; organic soil to sand). All plants were grown outdoors, under a black polypropylene shade fabric. Light extinction by the shade fabric measured with a Li-Cor quantum sensor (Li-Cor, Inc., Lincoln, NE, USA) on a clear day was $70 \%$. Thirty days after planting, half of the pots were moved out of the shade net and the other half stayed under the permanent shaded conditions. The light extinction value in the shade treatment is similar to that encountered under pastures in the region. Plants received ample water and were fertilized once a week with $50 \mathrm{ml}$ of a water soluble fertilizer solution per pot $(15: 30: 15 ; \mathrm{N}$, $\left.\mathrm{P}_{2} \mathrm{O}_{5}, \mathrm{~K}_{2} \mathrm{O} ; 3.5 \mathrm{~g} \mathrm{~L}^{-1}\right)$.

\section{Growth analysis}

Three harvests were made; the first was on the day shading treatment was imposed, and the others 17 and 34 days later $(n=5$ per harvest and treatment). At each harvest, plant material was divided into leaf, support tissue (stem and petiole) and root. Leaves were removed and their areas were measured using a leaf area meter (LI-3000, with conveyor belt assembly, LI-3050; Li-Cor, inc., Lincoln, NE, USA). Roots were washed free of soil using a manually manipulated jet spray of water. Plant dry mass was obtained by drying the plant material at $65{ }^{\circ} \mathrm{C}$ for $48 \mathrm{~h}$. At each harvest, the specific leaf area (ratio between total leaf area per plant and total leaf dry mass per plant, SLA), leaf area ratio (ratio between total leaf area per plant and total dry mass per plant, LAR) and leaf, support tissue and root mass ratios (respectively, the ratio between leaf, support tissue, and root dry mass per plant and total dry mass per plant, LMR SMR and RMR), were 
calculated. Relative growth rate (change in total dry mass per total dry mass of plant per day, RGR) was also calculated for each harvest interval. All of the above growth and biomass allocation parameters were calculated according to Hunt (1990) and the units were expressed according to Bugbee (1996). All responses were compared using the general linear model procedure of SYSTAT 7.0.1 for Windows (SPSS Inc., Chicago, USA). When appropriate, means were compared by post hoc contrasts.

\section{Gas exchange}

Gas exchange parameters were measured one day before the third harvest. A photosynthesis (A) versus irradiance (PFD) response curve, was measured outdoors, on a sunny day, between 9.00 and $11.00 \mathrm{~h}$ local time, on the most recent, fully expanded intact leaf of three plants per treatment using a portable photosynthesis system (Model LI6200, LI-COR, Inc., Lincoln, NE, USA). Gas exchange parameters were calculated on a leaf area basis. The light levels were obtained by intercepting the solar radiation with neutraldensity filters. After exposure to the lowest PFD, the plants were left for $15 \mathrm{~min}$ in the dark and measurements were made to obtain dark respiration $\left(R_{d}\right)$ values. Three replicate plants per treatment and one leaf per plant were sampled.

Photosynthesis vs. irradiance response data provided direct estimates of the highest measured value of photosynthetic rate $\left(A_{\max }\right)$. Apparent quantum yield of $\mathrm{CO}_{2}$ to incident irradiance $(\alpha)$ was calculated according to Thompson et al. (1992): the slope of a linear regression of three $R_{d}$ measurements and three low irradiance (ca. $65 \mu \mathrm{mol} \mathrm{m} \mathrm{m}^{-2} \mathrm{~s}^{-1}$ ) measurements of $\mathrm{CO}_{2}$ exchange, for each irradiance regime. The light compensation point was calculated as the ratio, $R_{d} / \alpha$. The calculated values were compared between treatments by two-sample $t$ test, using the Dunn-Sidak adjustment to the probabilities procedure of SYSTAT 7.0.1 for Windows (SPSS Inc., Chicago, USA)
Light response curves were fitted using the Von Bertalanffy equation (Horton \& Neufeld, 1998) and the nonlinear estimation procedure of STATISTICA 5.1 for Windows (StatSoft, Inc., Tulsa, USA):

$$
p=a+b\left(1-\exp ^{-k^{*} \mathrm{PFD}}\right)
$$

where $p=$ observed photosynthetic rate, $a=$ dark respiration rate, $b=$ maximum photosynthetic rate, and $k=$ apparent quantum yield.

\section{RESULTS AND DISCUSSION}

\section{Growth and biomass allocation}

The ANOVA revealed significant treatment $\times$ time interaction effect for SLA and LAR $\left(\mathrm{F}_{2,20} \geq 20.6 ; \mathrm{P}<0.001\right)$. Post hoc contrasts showed that both at 17 and at 34 days shaded plants had significantly higher SLA and LAR (Figure 1). The increase in SLA and LAR is a common response to shade in both woody and herbaceous plants (Dias Filho, 1995; 1997; Gloser \& Gloser, 1996; Groninger et al. 1996; Huante \& Rincón, 1998; Regnier \& Harrison, 1993) and is related to the plant's ability to offset photosynthesis limitation in whole plant relative growth rate (Björkman, 1981) through a greater interception of light per unit leaf tissue.

Plants grown under low light environment often shift biomass allocation to leaves to the detriment of roots and stems (Holt, 1995; Lambers \& Poorter, 1992). In the present study, no significant interaction (treatment $\times$ time) effect could be detected for the components of biomass allocation. However, the treatment effect was significant for $\mathrm{RMR}\left(\mathrm{F}_{2,20}=6.0 ; \mathrm{P}=0.02\right)$, with shaded plants allocating less biomass to root tissue (Figure 2). Figure 2 also shows a tendency for higher biomass allocation to leaves and support tissues in shaded plants, however, this apparent increase was only marginally significant $(\mathrm{P}=0.07)$.

Relative growth rate was significantly reduced by shade $(\mathrm{P}=0.02)$. However, the overall reduction was only $25 \%$ of RGR in sun plants (mean \pm s.d., $1.04 \pm 0.59$ vs. $0.78 \pm 0.63 \mathrm{~kg} \mathrm{~kg}^{-1} \mathrm{~d}^{1}$ ). 

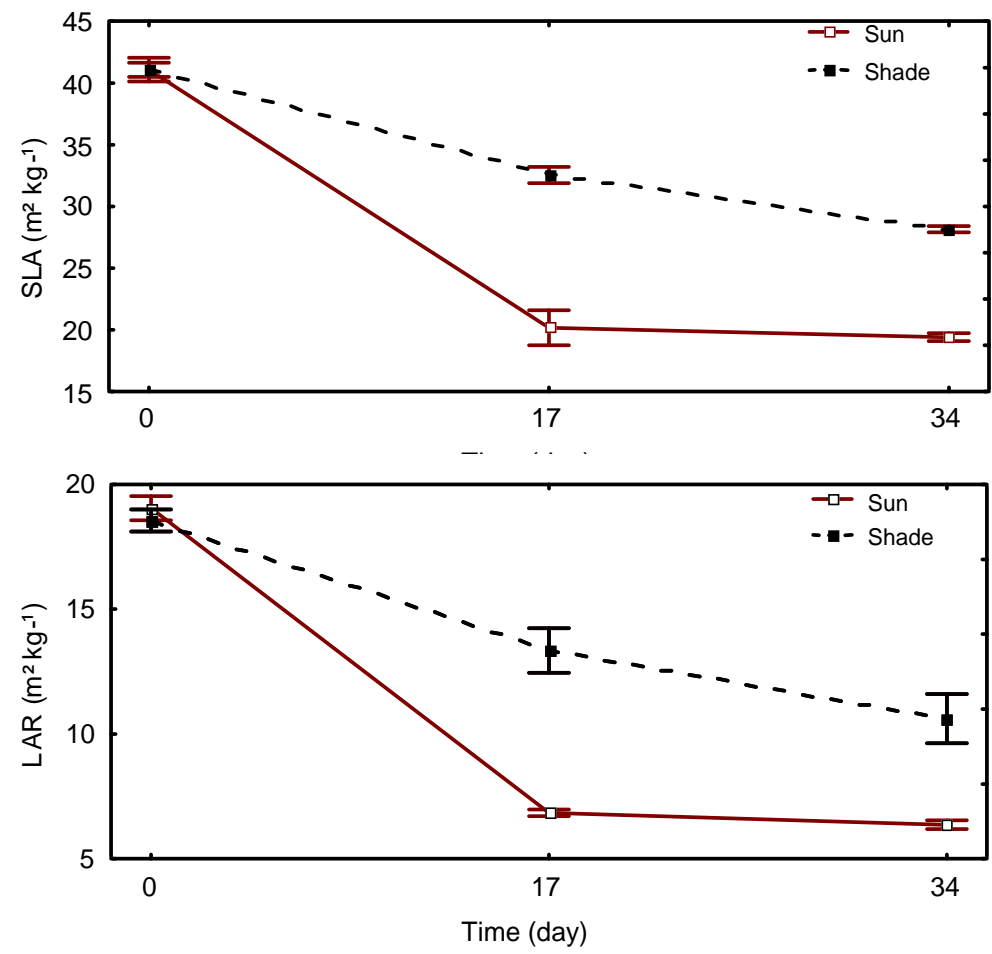

FIGURE 1. Change over time in specific leaf area (SLA) (mean \pm s.e., $n=5$ ) and leaf area ratio (LAR) (mean \pm s.e., $\mathrm{n}=5$ ) of $R$. fruticosa under sun (open symbols and solid line) or shade (closed symbols and dashed lines).

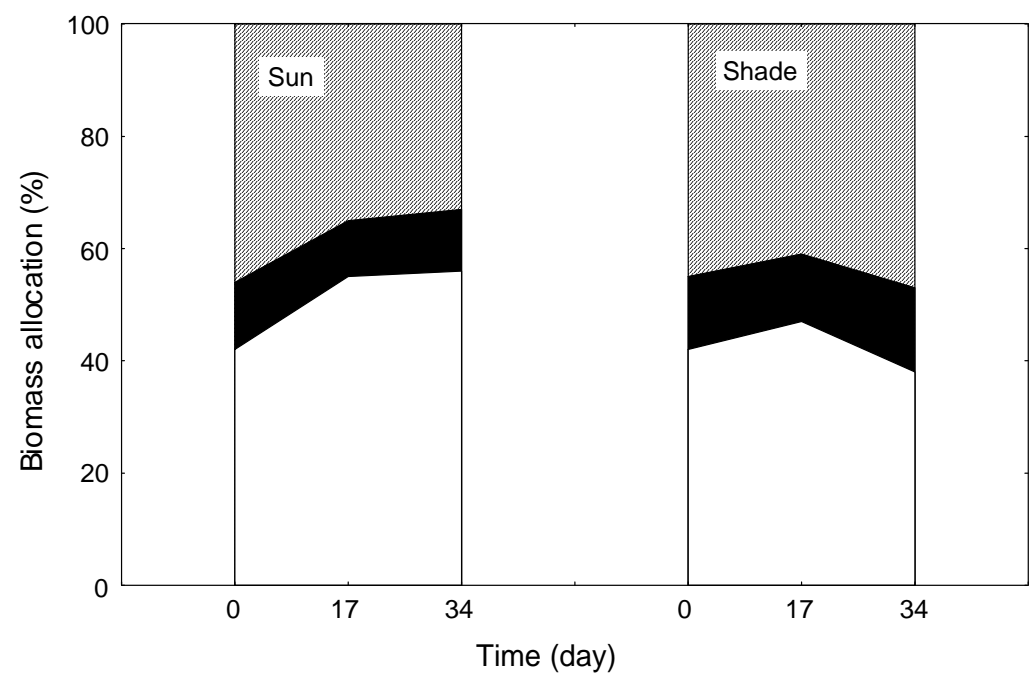

FIGURE 2. Mean fraction of biomass allocated to roots (blank area), stems (solid area) and leaves (hatched area) as a function of time and light environment in $R$. fruticosa. 
Difference in RGR was greatest at 17 days but very small at the last evaluation date (data not shown). As discussed in Lambers \& Poorter (1992), the potential of growth rate is greatly influenced by the amount of leaf area a plant realizes with a given total plant mass (LAR). In the present study, the increase in LAR in response to shade observed in $R$. fruticosa may have contributed to the relatively small reduction in RGR measured in shaded plants.

\section{Photosynthesis}

The shape of the light response curve of photosynthesis shows that shaded plants had a tendency to display lower assimilation rates under high light levels and higher assimilation at low $\left(<400 \mu \mathrm{mol} \mathrm{m}^{-2} \mathrm{~s}^{-1}\right)$ light levels (Figure 3). This photosynthetic behavior is similar to the one reported by Regnier et al. (1988) for the weed Abutilon theophrasti and by Dias Filho et al. (1996) for the tropical grass Panicum maximum grown under high or low light.

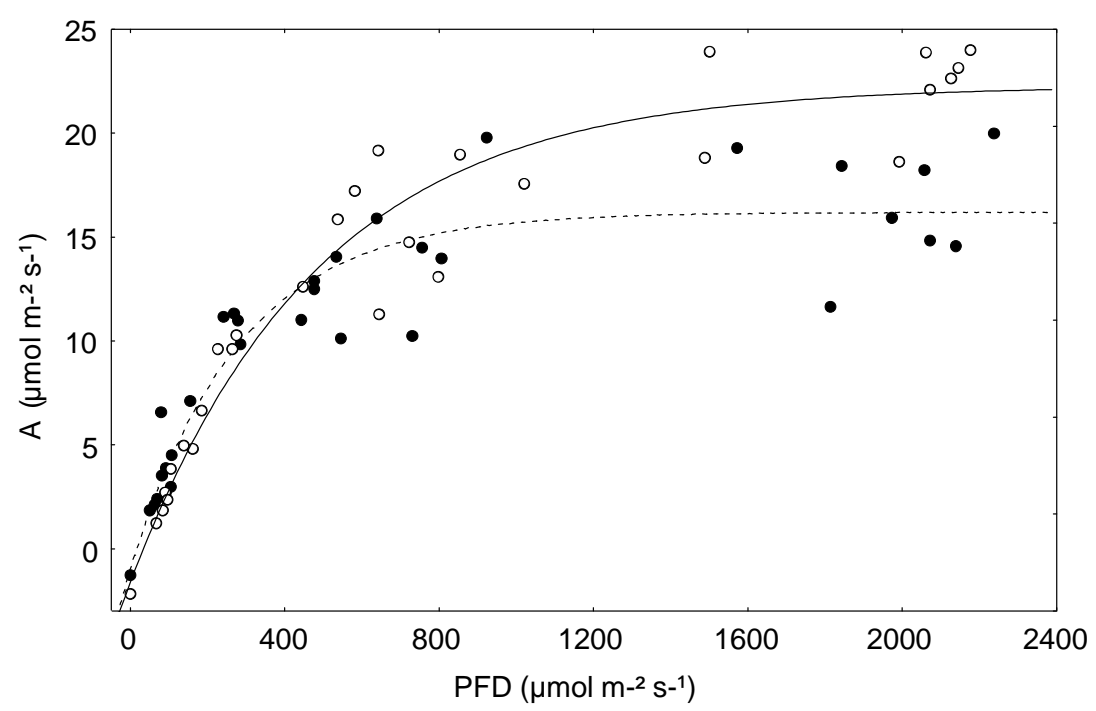

FIGURE 3. Fitted light (PFD) response curves of photosynthesis (A) in $R$. fruticosa grown under sun (open symbols and solid line) or shade (closed symbols and dashed line). The fitted Von Bertalanffy equations were:

$$
\begin{aligned}
& \mathbf{A}=-2.06+24.17\left(1-\mathrm{e}^{-0.0021 * \mathrm{PFD}}\right), \mathrm{r}^{2}=0.96, \text { Sun } \\
& \mathbf{A}=-1.31+19.0\left(1-\mathrm{e}^{-0.0035 * \mathrm{PFD}}\right), \mathrm{r}^{2}=0.89, \text { Shade }
\end{aligned}
$$

All photosynthetic parameters varied with light regime and, as judged from the calculated standard deviation, were probably determined with great precision (Table 1). Light-saturated photosynthesis $\left(A_{\max }\right)$ was lower for shaded plants. The apparent quantum efficiency, $\alpha$, was sensitive to the light regime during growth. Shade caused an average increase of $16 \%$ in $\alpha$ of $R$. fruticosa. If we consider the reciprocal of $\alpha$, the quantum requirement ( $\mathrm{mol} \mathrm{mol}{ }^{-1} \mathrm{CO}_{2}$ ), as a measure of efficiency of photosynthesis (Jones, 1992), shaded
$R$. fruticos $a$ was significantly $(\mathrm{t}=5.08, \mathrm{P}=0.007)$ more efficient than sun plants (mean \pm s.d., 18.05 \pm 0.25 vs. $21.62 \pm 1.19$ ). These quantum requirements represent photosynthetic efficiencies (in terms of absorbed PAR) of $13.22 \%$ and 11.04 $\%$, respectively for shade and sun plants. Mean dark respiration of shaded plants was $35 \%$ lower than in sun plants. Lower dark respiration is a common response to shade, and for the present study was probably a reflection of a lower demand for RGR and nutrient uptake rate known to occur 
in shaded plants (Cui \& Caldwell, 1997). The same tendency was observed for light compensation point that was $46 \%$ lower under shade. Most of the difference in $\mathrm{R}_{d} / \alpha$ between light regimes can be attributed to differences in dark respiration. Light compensation point of sun plants was similar to the value reported by Riddoch et al. (1991) to "weeds of gaps", while $\mathrm{R}_{\mathrm{d}} / \alpha$ of shade plants was close to the value found in "pioneer trees" by the same author.

TABLE 1. Photosynthetic parameters of Rolandra fruticosa under sun and shade regimes. Symbols and

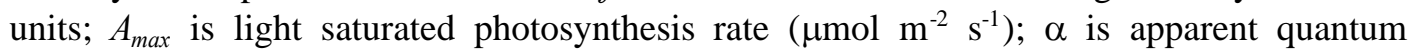
efficiency (mol $\left.\mathrm{CO}_{2} \mathrm{~mol}^{-1}\right) ; \mathrm{R}_{\mathrm{d}}$ is dark respiration $\left(\mu \mathrm{mol} \mathrm{m} \mathrm{m}^{-2} \mathrm{~s}^{-1}\right.$ ) and $\mathrm{R}_{\mathrm{d}} / \alpha$ is light compensation point $\left(\mu \mathrm{mol} \mathrm{m} \mathrm{m}^{-2}\right)$. Values are means ( \pm s.d.), $\mathrm{n}=3$.

\begin{tabular}{llll}
\hline Parameter & Sun & Shade & $P$ values $^{1}$ \\
\hline$A_{\max }$ & 24.0 & 19.96 & - \\
$\alpha$ & $0.046(0.002)$ & $0.055(0.001)$ & 0.011 \\
$\mathrm{R}_{\mathrm{d}}$ & $2.07(0.12)$ & $1.34(0.06)$ & 0.002 \\
$\mathrm{R}_{\mathrm{d}} / \alpha$ & $44.64(0.31)$ & $24.19(0.71)$ & $<0.001$ \\
\hline
\end{tabular}

${ }^{1}$ Differences between light regimes were analyzed by two-sample $t$ test, using Dunn-Sidak adjustment to the probabilities.

Although $R$. fruticosa is a typical weed of open-unshaded areas (Dias Filho, 1990), the results found in this study indicate that this species has the plasticity to acclimate to reduced light conditions by reallocation of dry mass, altered leaf morphology and decreased respiration. These physiological and morphological adaptations make this species photosynthetically efficient under low irradiance. Even though these acclimation changes are advantageous from a physiological viewpoint, it may not represent the ecological optimum for the plant. Because shade plants allocate a higher proportion of biomass to leaf area or mass, and a smaller proportion to roots than do sun plants, it could be speculated that $R$. fruticosa plants developed under shade may be relatively more vulnerable to climatic edaphic stress factors, such as drought or low nutrient availability. It can also be inferred that recovery from stresses that reduce or eliminate the aerial part, like mowing, fire or herbivory would be more difficult in shaded plants.

\section{ACKNOWLEDGMENTS}

To one anonymous reviewer for the valuable suggestions to improve this manuscript.

\section{LITERATURE CITED}

BJÖRKMAN, O. Responses to different quantum flux densities. In: LANGE, O. L., NOBEL, P. A.; OSMOND, C. B.; ZIEGLER, H. (Eds.). Physiological plant ecology. Berlin: Springer-Verlag, 1981. p.57-107. (Encyclopedia of Plant Physiology, 12 A).

BUGBEE, B.G. Growth analysis and yield components. In: SALISBURY, F.B. (Ed.). Units symbols, and terminology for plant physiology: a reference for presentation of research results in the plant science. New York: Oxford University Press, 1996. p.115-119.

CUI, M.; CALDWELL, M.M. Shading reduces exploitation of soil nitrate and phosphate by Agropyrun desertorum and Artemisia tridentata from soils with patchy and uniform nutrient distribution. Oecologia, v.109, p.177-183, 1997. 
DIAS FILHO, M.B. Plantas invasoras em pastagens cultivadas da Amazônia: estratégias de manejo e controle. Belém: Embrapa-CPATU, 1990. 103p. (EmbrapaCPATU. Documentos, 52).

DIAS FILHO, M. B. Physiological responses of Vismia guianensis to contrasting light environments. Rev. Bras. Fisiol. Veg., v.7, p.35-40, 1995.

DIAS FILHO, M.B.; CHAGAS JÚNIOR, A.F.; CARVALHO, C.J.R. de. Respostas morfológicas e fisiológicas de Panicum maximum a diferentes condições de luminosidade. In: REUNIÃO ANUAL DA SOCIEDADE BRASILEIRA DE ZOOTECNIA, 33., 1996, Fortaleza. Anais... Fortaleza: SBZ, 1996. p.62-64.

DIAS FILHO, M.B. Physiological responses of Solanum crinitum to contrasting light environments. Pesq. Agropec. Bras., v.32, p.789-796, 1997.

GLOSER, V., GLOSER, J. Acclimation capability of Clamoagrostis epigejos and $C$. arundinaceae to changes in radiation environment. Oecologia, v.32, p.202-212, 1996.

GRONINGER, J.W.; SEILER, J.R., PETERSON, J.A.; KREH, R.E. Growth and photosynthetic responses of four Virginia Piedmont tree species to shade. Tree Physiology, v.16, p.773-778, 1996.

HOLT, J.S. Plant response to light: a potential tool for weed management. Weed Sci., v.43, p.474-482, 1995.

HORTON, J.L.; NEUFELD, H. S. Photosynthetic responses of Microstegium vimineum (Trin.) A. Camus, a shade-tolerant, $\mathrm{C}_{4}$ grass, to variable light environments. Oecologia, v.114, p.11-19, 1998.
HUANTE, P.; RINCÓN, E. Responses to light changes in tropical deciduous woody seedlings with contrasting growth rates. Oecologia, v.113, p.53-66, 1998.

HUNT, R. Basic growth analysis: plant growth analysis for beginners. London: Unwin Hyman. 1990. 112p.

JONES, H.G. Plants and microclimate: a quantitative approach to environmental plant physiology. Second ed. Cambridge: Cambridge University Press. 1992. 428p.

LAMBERS, H.; POORTER, H. Inherent variation in growth rate between higher plants: a search for physiological causes and ecological consequences. Adv. Ecol. Res., v.23, p.187-261, 1992.

OGREN, E.; SUNDIN, U. Photosynthetic responses to variable light: a comparison of species form contrasting habitats. Oecologia, v.106, p.18-27, 1996.

PATTERSON, D.T. Effects of environmental stress on weed/crop interactions. Weed Sci., v.43, p.483-490, 1995.

REGNIER, E.; HARRISON, S.K. Compensatory responses of common cocklebur (Xanthium strumarium) and velvetleaf (Abutlion theophrasti) to partial shading. Weed Sci, v.41, p.541-547, 1993.

REGNIER, E.E.; SALVICCI, M.E.; STOLLER, E.W. Photosynthesis and growth responses to light in soybean (Glycine max) and three broadleaf weeds. Weed Sci, v.36, p.487496, 1988.

RIDDOCH, I.; GRACE, J.; FASEHUN, F.E.; RIDDOCH, B.; LAPIDO, D.O. Photosynthesis and successional status of seedlings in a tropical semi-deciduous rain 
forest in Nigeria. Journal of Ecology, v.79, p.491-503, 1991.

SULTAN, S.E.; WILCZEK, A.M., BELL, D.L., HAND, G. Physiological response to complex environments in annual Polygonum species of contrasting ecological breadth. Oecologia, v.115, p.564-578, 1998.
THOMPSON, W.A.; HUANG, L.-K.; KRIEDEMANN, P.E. Photosynthetic response to light and nutrients in suntolerant and shade-tolerant rainforest trees. II. Leaf gas exchange and component processes of photosynthesis. Australian Journal of Plant Physiology, v.19, p.1942. 1992. 